\title{
Pengaruh Rasio Profitabilitas, Solvabilitas, dan Likuiditas terhadap Harga Saham Pada Perusahaan Sektor Pertambangan yang Terdaftar di BEI Periode 2014-2018
}

\author{
Januardin Manullang \\ Medan, Indonesia \\ januardin.manullang@gmail.com
}

Phillip

Medan, Indonesia

limphilip97@gmail.com

\author{
Hanson Sainan \\ Medan, Indonesia \\ a1.29227@ sutomo-mdn.sch.id
}

\author{
Winson Halim \\ Medan, Indonesia \\ Winson.halim@yahoo.com
}

\begin{abstract}
ABSTRAK
Tujuan dari penelitian ini adalah untuk menganalisis pengaruh Return on Equity, Debt to Equity Ratio, Quick Ratio, dan Earning Per Share terhadap Harga Saham. Penelitian ini bertujuan sebagai bahan pertimbangan untuk membantu investor menentukan pengaruh rasio keuangan terhadap harga saham sehingga mereka dapat menentukan sektor mana yang baik untuk investasi. Sampel penelitian ini adalah tujuh puluh lima laporan keuangan perusahaan pertambangan yang terdaftar di Bursa Efek Indonesia menggunakan metode penelitian kuantitatif. Analisis regresi berganda digunakan sebagai teknik analisis. Hasil penelitian menunjukkan bahwa Return on Equity dan Earning Per Share memiliki pengaruh signifikan terhadap Harga Saham secara parsial sedangkan Debt to Equity Ratio dan Quick Ratio tidak berpengaruh terhadap Harga Saham secara parsial.
\end{abstract}

Keywords : Return on Equity, Debt to Equity Ratio, Quick Ratio, Earning Per Share, Stock Price

\section{Pendahuluan}

Sebagai tempat terjadinya perdagangan surat berharga, pasar modal memiliki peran penting dalam perekonomian dan dunia bisnis di Indonesia yang perkonomiannya terus berkembang. Hal ini dikarenakan perusahaan - perusahaan di Indonesia berusaha untuk menjadi perusahaan terbuka di Bursa Efek Indonesia (go-public) agar mampu memenuhi kemampuannya dalam hal pemenuhan dana supaya perusahaan dapat berjalan dengan baik dan menghasilkan keuntungan.

Pasar modal juga menjadi pilihan yang tepat bagi investor untuk melakukan investasi dalam aset keuangan. Dengan membeli surat saham dari sebuah perusahaan, maka seseorang memiliki hak untuk mendapatkan keuntungan dari perusahaan tersebut. Oleh karena itu, investor harus mempertimbangkan banyak hal sebelum melakukan investasi pada sebuah perusahaan, seperti melihat harga saham, laporan keuangan, ataupun faktor eksternal lainnya. Faktor eksternal tersebut termasuk dengan diberlakukannya kebijakankebijakan keuangan di Indonesia ataupun kesepakatan-kesepakatan yang dilakukan Indonesia dengan manca negara.

Sektor pertambangan memiliki peran yang sangat penting bagi perekonomian nasional, baik dalam sektor fiscal, moneter, 
maupun sektor riil. Peran pertambangan terlihat jelas dimana pertambangan menjadi salah satu sumber pendapatan negara.. Hal ini akan menarik para investor untuk melakukan investasi pada perusahaan - perusahaan di sektor ini dimana ketertarikan para investor tersebut akan memperngaruhi harga saham perusahaan - perusahaan di sektor ini.

Berdasarkan uraian diatas peneliti ingin meneliti lebih lanjut mengenai rasio keuangan yang mengarah ke harga saham perusahaan. Permasalahan yang akan diteliti dalam penelitian ini adalah bagaimana tingkat penghasilan laba bersih yang didapat perusahaan, total hutang, efisiensi dalam penggunaan aset dan uang tunai yang digunakan untuk membayar hutang yang terkait dalam mendorong nilai saham perusahaan. Data laba bersih perusahaan, pengelolaan hutang, dan efisiensi dalam penggunaan aset dapat dilihat pada table berikut ini:

Tabel 1.1

Perkembangan Laba Bersih, Total Hutang, Aktiva Lancardan Harga Saham Perusahaan Pertambangan Tahun 2014-2018 (dalam Rupiah penuh)

\begin{tabular}{|c|c|c|c|c|c|}
\hline $\begin{array}{l}\text { Kode } \\
\text { Emiten }\end{array}$ & Tahun & Laba Bersih & Total Hutang & Aktiva Cepat & $\begin{array}{l}\text { Harga } \\
\text { Saham }\end{array}$ \\
\hline \multirow{5}{*}{ ARTI } & 2014 & 30.077 .661 .785 & 806.258 .485 .963 & 967.412 .481 .687 & 101 \\
\hline & 2015 & 17.803 .077 .238 & 763.271 .737 .857 & 1.686 .021 .077 .511 & 170 \\
\hline & 2016 & 9.285 .490 .258 & 885.646 .642 .382 & 823.275 .555 .476 & 50 \\
\hline & 2017 & 28.208 .281 .803 & 656.641 .763 .709 & 586.741 .573 .892 & 50 \\
\hline & 2018 & 32.803 .582 .081 & 749.620 .571 .942 & 587.404 .124 .231 & 50 \\
\hline \multirow{5}{*}{ CTTH } & 2014 & 1.014 .318 .138 & 285.803 .117 .172 & 274.529 .892 .516 & 67 \\
\hline & 2015 & 1.949 .752 .745 & 316.679 .237 .740 & 319.565 .858 .417 & 56 \\
\hline & 2016 & 20.881 .438 .764 & 301.007 .248 .281 & 331.400 .378 .677 & 80 \\
\hline & 2017 & 4.716 .765 .807 & 378.839 .294 .845 & 138.909 .734 .316 & 99 \\
\hline & 2018 & 5.205 .032 .919 & 408.160 .870 .584 & 170.004 .731 .615 & 119 \\
\hline \multirow{3}{*}{ PTBA } & 2014 & 2.019 .214 .000 .000 & 6.141 .181 .000 .000 & 6.383 .445 .000 .000 & 2.500 \\
\hline & 2015 & 2.037.111.000.000 & 7.606.496.000.000 & 6.365 .301 .000 .000 & 905 \\
\hline & 2016 & 2.024 .405 .000 .000 & 8.024 .369 .000 .000 & 8.349 .927 .000 .000 & 2.500 \\
\hline
\end{tabular}

\begin{tabular}{|c|c|c|c|c|}
2017 & 4.547 .232 .000 .000 & 8.187 .497 .000 .000 & 9.961 .733 .000 .000 & 2.460 \\
\hline 2018 & 5.121 .112 .000 .000 & 7.903 .237 .000 .000 & 10.188 .199 .000 .000 & 4.300 \\
\hline
\end{tabular}

Sumber : Bursa Efek Indonesia (Peneliti)

Pada Tabel 1.1 di atas menunjukkan terlihat memang fenomena yang terjadi tidak sesuai dengan konsep yang selama ini terjadi dimana seharusnya ketika laba bersih setelah pajak, total hutang, , dan aktiva cepat meningkat harusnya dapat mendorong harga saham tetapi hal tersebut tidak terjadi pada perusahaan ARTI, CTTH dan PTBA. Oleh karena itu, penelitian ini dilakukan dengan tujuan untuk mengetahui "Pengaruh ROE, DER, QR dan EPS terhadap Harga Saham”.

\section{Landasan Teori}

\section{II.1 Return On Equity}

Untuk mengukur tingkat laba perusahaan dapat diukur melalui rasio Profitabilitas. Rasio Profitabilitas yang digunakan dalam penelitian ini adalah Return on Equity (ROE). Menurut Murhadi (2013:96), "Return On Equity (ROE) mencerminkan seberapa besar return yang dihasilkan bagi pemegang saham atas setiap rupiah uang yang ditanamkannya."

$$
\text { Return On Equity }=\frac{\text { Laba bersih stlh pajak }(\text { EAT) }}{\text { Total Ekuita } s \text { (Equity) }}
$$

\section{II.2 Debt to Equity Ratio}

Debt to Equity Ratio merupakan rasio yang digunakan untuk menilai utang dengan ekuitas”. Sedangkan Sartono (2012:257), “ Leverage adalah penggunaan asset dan sumber dana (sources of funds) oleh perusahaan yang memiliki biaya tetap (beban tetap) dengan maksud agar meningkatkan keuntungan potensial pemegang saham Wira (2015:61)," rasio hutang yang tinggi belum tentu buruk. Karena hutang bias berarti buruk, bisa berarti bagus. Saat ekonomi sulit dan tingkat suku bunga tinggi, perusahaan yang memiliki rasio hutang tinggi dapat mengalami masalah. Sebaliknya saat ekonomi naik dan suku bunga rendah, hutang dapat digunakan untuk melakukan ekspansi dan ujungujungnya meningkatkan keuntungan”.

Debt to Equity Ratio $=\frac{\text { Total Utang }(\text { Debt })}{\text { Total Ekuitas }(\text { Equity })}$ 


\section{II.3 Quick Ratio}

Untuk mengukur efisiensi penggunaan aktiva lancar dalam membayar hutang perusahaan diukur melalui rasio likuiditas. Rasio likuiditas yang digunakan dalam penelitian ini adalah Quick Ratio (QR). Menurut Sudana (2011:21), " Quick Ratio (QR) adalah seperti Current Ratio tetapi persediaan tidak diperhitungkan karena kurang likuid dibandingkan kas, surat berharga, dan piutang".

$$
\text { Quick Ratio }=\frac{\text { Aktiva Lancar }- \text { Persediaan }}{\text { Utang Lancar }}
$$

\section{II.4 Earning Per Share}

Menurut Darmadji dan Fakhruddin (2012:154), Earning Per Share merupakan rasio yang menunjukkan bagian laba untuk setiap saham dibagikan dalam bentuk dividen. Laba Per Saham adalah besarnya laba bersih atas setiap lembar saham biasa. Ketika mengevaluasi perusahaan, adalah tidak cukup hanya mengetahui bagaimana laba bersih meningkat atau menurun,investor biasanya akan lebih fokus dengan melihat bagaimana perubahan laba bersih yang dihasilkan investee telah mempengaruhi investasinya dan harga saham.

Earning After tax

$$
\text { Earning Per Share }
$$

$$
=\text { Jumlah Saham yg Beredar }
$$

\section{II.5 Harga Saham}

Menurut Zubir (2011:)," Harga saham adalah cerminan dari pengelolaan perusahaan yang baik oleh manajemen untuk menciptakan dan memanfaatkan prospek usaha,sehingga memperoleh keuntungan dan mampu memenuhi tanggung jawabnya terhadap pemilik, karyawan, masyarakat, dan pemerintah (stakeholders).

\section{Harga Saham $=$ Closing Price}

\section{II.6 Kerangka Konseptual}

Dalam mendukung penelitian ini, berikut adalah beberapa penelitian yang digunakan sebagai referensi dan acuan dalam penelitian ini. Penelitian yang dilakukan Astrid Amanda, Darminto dan Achmad Husaini (2011), dengan hasil pengujian menunjukkan bahwa variabel DER, ROE, EPS, dan PER berpengaruh secara simultan terhadap Harga Saham. Hasil penelitian juga menunjukkan bahwa secara parsial variabel DER, ROE, dan EPS berpengaruh secara signifikan terhadap Harga Saham, sedangkan variabel PER tidak berpengaruh secara signifikan terhadap Harga Saham pada perusahaan food and beverages.

Penelitian yang dilakukan oleh Dorothea Ratih, Apriatni E.P, Saryadi (2013), dengan hasil penelitian menunjukkan bahwa variabel DER memiliki pengaruh negatif signifikan terhadap Harga Saham. Variabel EPS, PER dan DER memiliki pengaruh signifikan terhadap Harga Saham. Variabel EPS, PER, DER, dan ROE secara simultan memiliki pengaruh yang signifikan terhadap Harga Saham yaitu sebesar. Hal ini menunjukkan bahwa keseluruhan EPS, PER, DER, dan ROE perusahaan Pertambangan periode 2010 2012 dapat mempengaruhi Harga Saham.

Penelitian yang dilakukan oleh Reni uryaningrum (2015), dengan hasil penelitian menunjukkan bahwa CR, ROE, EES secara parsial berpengaruh signifikan positif, sedangkan DAR berpengaruh signifikan negatif terhadap harhga saham dan EPS berpengaruh positif dan signifikan terhadap harga saham. Sementara CR, DER, DAR, ROE dan EPS secara simultan berpengaruh signifikan terhadap harga saham. Kelima variabel independen menunjukkan pengaruh signifikan secara simultan terhadap harga saham.

Penelitian yang dilakukan oleh Ummu Hanie dan Muhammad Saifi (2018), dengan hasil penelitian menunjukkan bahwa ketiga variabel tersebut berpengaruh signifikan secara simultan terhadap Harga Saham. Secara parsial, CR dan DER berpengaruh positif dan signifikan terhadap Harga Saham, sedangkan QR berpengaruh secara negative terhadap Harga Saham.

Berdasarkan hasil penelitian yang diperoleh penelitian sebelumnya serta landasan teori diatas, maka dapat digambarkan suatu kerangka konseptual dilihat dari Gambar 2.1 sebagai berikut:

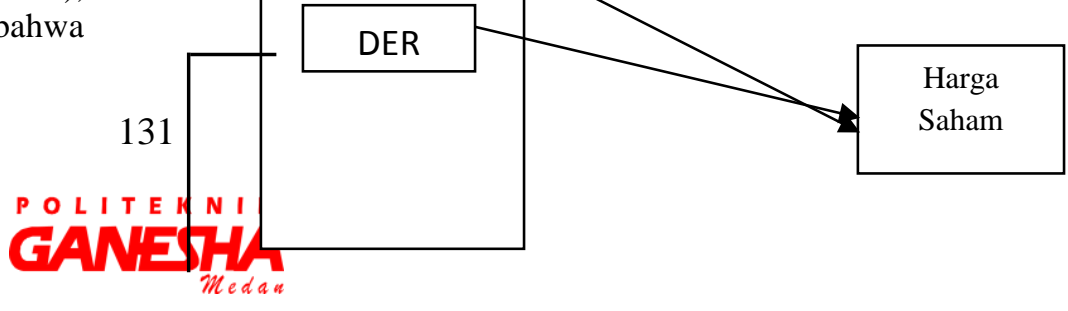




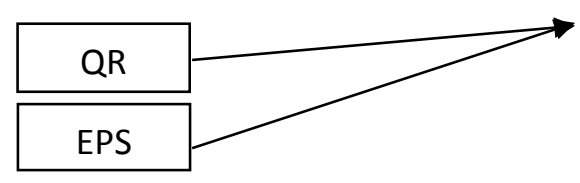

Gambar 2.1 Kerangka Konseptual

Harga saham merupakan objek yang paling diminati oleh para investor didalam pasar modal. Perusahaan - perusahaan berlomba - lomba untuk menarik perhatian investor dalam membeli saham agar dapat meningkatkan investasi saham di perusahaan. Jika investasi dapat meningkat maka kinerja perusahaan juga akan meningkat.

$\mathrm{H}_{1}$ :Return on Equity berpengaruh terhadap harga saham pada Perusahaan Pertambangan yang terdaftar di BEI periode 2014-2018.

$\mathrm{H}_{2}$ : Debt to Equity Ratio berpengaruh terhadap harga saham pada Perusahaan Pertambangan yang terdaftar di BEI periode 2014-2018.

$\mathrm{H}_{3}$ : Quick Ratio berpengaruh terhadap harga saham pada Perusahaan Pertambangan yang terdaftar di BEI periode 2014-2018.

$\mathrm{H}_{4}$ : Earning Per Share berpengaruh terhadap harga saham pada Perusahaan Pertambangan yang terdaftar di BEI periode 2014-2018.

$\mathrm{H}_{5}$ : Return on Equity, Debt to Equity Ratio, Quick Ratio dan Earning Per Share berpengaruh terhadap harga saham pada Perusahaan Pertambangan yang terdaftar di BEI periode 2014-2018.

\section{Metodologi Penelitian}

Penelitian ini menggunakan pendekatan kuantitatif dengan tujuan untuk menguji hipotesis yang telah ditetapkan.Data penelitian yang digunakan adalah data sekunder yang diperoleh dari Bursa Efek Indonesia berupa laporan keuangan pada perusahaan - perusahaan sektor Pertambangan periode 2014-2018. Populasi dalam penelitian ini adalah seluruh perusahaan Pertambangan yang terdaftar di Bursa Efek Indonesia (BEI) mulai tahun $2014-2018$ yang terdiri dari 42 perusahaan.Teknik pengambilan sampel dengan menggunakan purposive sampling jumlah sampel yang didapatkan yaitu 15 perusahaan dan dikalikan dengan tahun penelitian maka didapatkan 75 data penelitan.

Kriteria untuk pemilihan sampel pemilihan ini adalah:

1. Perusahaan pertambangan yang terdaftar di Bursa Efek Indonesia pada tahun 2014 $-2018$.

2. Perusahaan pertambangan yang mempublikasikan laporan keuangannya secara lengkap dan berturut turut pada periode $2014-2018$.

3. Perusahaan yang memiliki laba positif selama tahun $2014-2018$.

Metode penelitian yang digunakan adalah analisis data model regresi linier berganda melalui aplikasi Statistical Package for Social Science (SPSS).

\section{IV.1. Hasil Penelitian dan Pembahasan}

Pada penelitian ini sampel pada perusahaan pertambangan yang terdaftar di BEI yang berjumlah 15 perusahaan dengan periode penelitian dari tahun 2014-2018, sehingga data penelitian yang diperoleh berjumlah 75. Pengujian penelitian ini menggunakan Uji Asumsi Klasik. Didalam Uji persyaratan analisis ini ada 4 yaitu pengujian normalitas, multikolinearitas, autokorelasi, dan heteroskedastisitas.

1. Uji Normalitas

Uji normalitas digunakan untuk menguji apakah dalam model regresi, variabel pengganggu atau residual memiliki distribusi normal. Hasil uji normalitas dapat diliat di bawah ini:

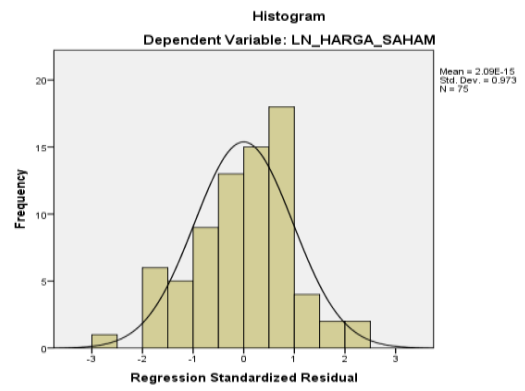

Gambar 4.1 Grafik Histogram

Sumber : Hasil pengolahan data SPSS 


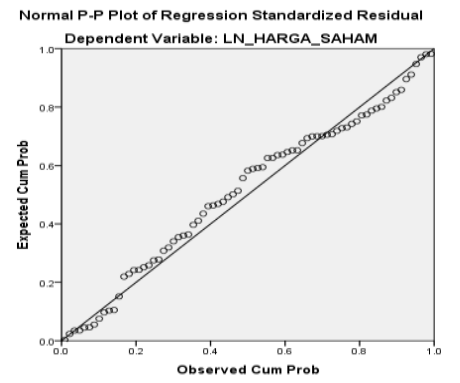

Gambar 4.2 Grafik Normal PP-Plot

Sumber : Hasil Pengolahan Data SPSS

Dengan melihat tampilan grafik histogram maupun grafik PP-PloT, disimpulkan bahwa grafik histogram memberikan data residual berdistribusi normal karena dapat dilihat dari kurva yang berbentuk seperti lonceng. Sedangkan pada grafik normal PP-Plot data residual berdistribusi normal karena titik-titik menyebar di sekitar garis diagonal, dan mengikuti arah garis diagonal, baik yang di atas, maupun di bawah garis diagonal.

Tabel IV.1 Kolmogrov Smirnov

\begin{tabular}{|ll|r|}
\hline N & $\begin{array}{r}\text { Unstandardiz } \\
\text { ed Residual }\end{array}$ \\
Normal & Mean & 75 \\
Parameters & $0 \mathrm{E}-7$ \\
& Std. & Deviation \\
Most Extreme & Absolute & .82144049 \\
Differences & Positive & .091 \\
Kolmogorov-Smirnov Z & .060 \\
Asymp. Sig. (2-tailed) & -.091 \\
a. Test distribution is Normal. & .789 \\
\multicolumn{2}{l|}{ b. Calculated from data. } \\
\multicolumn{2}{l|}{ Sumber : Hasil Pengolahan Data SPSS }
\end{tabular}

Nilai Asymp.Sig.(2-tailed) sebesar 0,561 lebih besar dari 0,05. Jadi berdasarkan uji normalitas baik menggunakan grafik maupun statistik menunjukkan bahwa model regresi memenuhi asumsi normalitas.

2. Uji Multikolinieritas

Uji multikolinearitas bertujuan untuk menguji apakah model regresi mempunyai korelasi antar variabel bebas. Model regresi yang baik adalah tidak terjadi multikolinearitas. Untuk mendeteksi ada atau tidaknya multikolinearitas di dalam model regresi dapat dilihat dari nilai tolerance dan lawannya dan
Variance inflation factor (VIF), dengan nilai tolerance $\leq 0,10$ dan dengan nilai $\mathrm{VIF} \geq 10$.

\begin{tabular}{|c|c|c|}
\hline \multirow{2}{*}{ Model } & \multicolumn{2}{|c|}{ Collinearity Statistics } \\
\cline { 2 - 3 } & Tolerance & VIF \\
\hline (Constant) & & \\
LN_ROE & .173 & 5.791 \\
LN_DER & .744 & 1.343 \\
LN_QR & .790 & 1.265 \\
LN_EPS & .167 & 5.987 \\
\hline
\end{tabular}

a.

Dependent Variable: LN_Harga_Saham Sumber : Hasil Pengolahan Data SPSS

Nilai tolerance yang diperoleh untuk variabel Return on Equity (X1) adalah sebesar (0,173), Debt to Equity Ratio (X2) adalah sebesar (0,744), Quick Ratio (X3) adalah sebesar (0,790), dan Earning Per Share (X4) adalah sebesar $(0,167)$. Karena nilai tolerance yang diperoleh setiap variabel lebih besar dari 0,10 maka dapat disimpulkan bahwa tidak terjadi multikolinearitas. Nilai VIF yang diperoleh untuk variabel Return on Equity (X1) adalah sebesar (5,791), Debt to Equity Ratio (X2) adalah sebesar (1,343), Quick Ratio (X3) adalah sebesar (1,265), dan Earning Per Share (X4) adalah sebesar $(5,987)$. Dikarenakan nilai VIF yang diperoleh untuk setiap variabel lebih kecil dari 10, maka dapat disimpulkan tidak terjadi gejala multikolinearitas antar variabel independen dalam model regresi setelah transformasi data. 3. Uji Autokorelasi

Uji ini bertujuan untuk melihat apakah dalam model regresi linear ada korelasi antara kesalahan pengganggu pada periode $t$ dengan kesalahan pada periode $\mathrm{t}-1$. Model regresi yang baik adalah tidak terjadi autokorelasi.

Table IV.3 Uji Autokolerasi 


\section{Model Summaryb}

\begin{tabular}{|l|c|r|r|r|r|}
\hline $\begin{array}{l}\text { Mo } \\
\text { del }\end{array}$ & $\mathrm{R}$ & $\begin{array}{c}\mathrm{R} \\
\text { Squar } \\
\mathrm{e}\end{array}$ & $\begin{array}{r}\text { Adjusted } \\
\text { R Square }\end{array}$ & $\begin{array}{c}\text { Std. Error } \\
\text { of the } \\
\text { Estimate }\end{array}$ & $\begin{array}{l}\text { Durbin- } \\
\text { Watson }\end{array}$ \\
\hline 1 & $.867^{\mathrm{a}}$ & .752 & .738 & .84458 & 2.621 \\
\hline
\end{tabular}

a. Predictors: (Constant), LN_EPS, LN_QR,

LN DER, LN ROE

b. Dependent Variable: LN_HARGA_SAHAM

Sumber : Hasil Pengolahan Data SPSS

Dari tabel diatas, hasil uji Durbin-

Watson menunjukan angka sebesar 2,621.

Dari tabel DW untuk " $k$ " = 4 (jumlah variabel bebas) dan $\mathrm{N}=75$ (jumlah sampel), besar $\mathrm{dl}$ $($ batas bawah $)=1,5151$ dan du (batas atas $)=$ 1,7390; $4-\mathrm{du}=2,261 ; 4-\mathrm{dl}=2,4849$. Dalam penelitian ini $4-\mathrm{dl}<\mathrm{d}<4$ atau $2,4849<$ $2,621<4$, maka pengujian maka pengujian tidak dapat disimpulkan.

Karena pengujian autokorelasi dengan menggunakan durbin-watson tidak menghasilkan suatu kesimpulan, maka akan dilanjutkan dengan menggunakan uji RunTest. Adapun hasil uji Run-Test sebagai berikut :

Tabel 4.4

Hasil Uji AutoKolerasi dengan RunTest

Runs Test

\begin{tabular}{|l|r|}
\hline & $\begin{array}{r}\text { Unstandardized } \\
\text { Residual }\end{array}$ \\
\hline Test Value & .17528 \\
Cases < Test & 37 \\
Value & \\
Cases >= Test & 38 \\
Value & \\
Total Cases & 75 \\
Number of Runs & 38 \\
Z & -.115 \\
Asymp. Sig. (2- & .909 \\
tailed) & \\
\hline
\end{tabular}

a. Median

Sumber : Pengolahan Data SPSS
Berdasarkan hasil output diatas, diperoleh nilai signifikan sebesar 0,909 > 0,05 sehingga dapat disimpulkan bahwa tidak terjadi autokorelasi pada model regresi ini.

4. Uji Heteroskedastisitas

Bertujuan untuk menguji apakah dalam model regresi terjadi ketidaksamaan variance dari residual satu pengamatan ke pengamatan yang lain. Model regresi yang baik adalah jika tidak terjadi heteroskedastisitas.

Hasil uji heteroskedastisitas dapat dilihat dibawah ini :

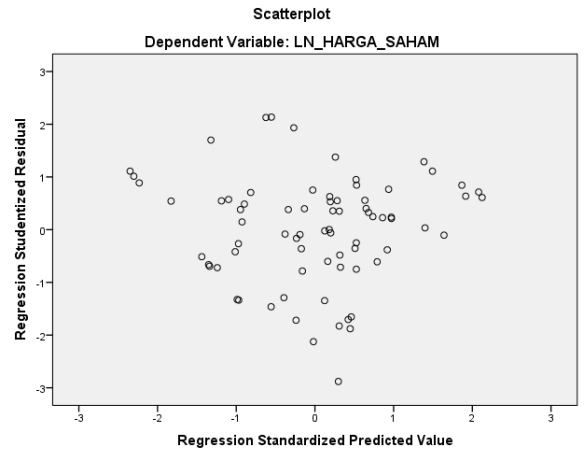

Gambar 4.3 Grafik Scatterplot

Sumber : Hasil Pengolahan Data SPSS

Dari gambar diatas, memperlihatkan bahwa titik-titik menyebar secara acak, baik di atas maupun dibawah angka 0 pada sumbu $Y$. Dengan demikian dapat disimpulkan tidak terjadi heteroskedastisitas pada model regresi setelah transformasi data.

IV.2. Analisis Linier Berganda Tabel 4.5 Hasil Analisis Regresi Linear Berganda

a. Dependent Variable: LN_Harga_Saham

Sumber : Hasil Pengolahan Data SPSS

\begin{tabular}{|c|c|c|c|c|c|c|}
\hline \multirow{2}{*}{\multicolumn{2}{|c|}{ Model }} & \multicolumn{2}{|c|}{$\begin{array}{l}\text { Unstandardized } \\
\text { Coefficients }\end{array}$} & \multirow{2}{*}{$\begin{array}{c}\begin{array}{c}\text { Standardize } \\
d \\
\text { Coefficients }\end{array} \\
\text { Beta }\end{array}$} & \multirow[t]{2}{*}{$\mathrm{t}$} & \multirow[t]{2}{*}{ Sig. } \\
\hline & & $B$ & $\begin{array}{l}\text { Std. } \\
\text { Error }\end{array}$ & & & \\
\hline & $\begin{array}{l}\text { (Constan } \\
\text { t) }\end{array}$ & 1.914 & .781 & & 2.449 & .017 \\
\hline & LN_ROE & -.453 & .156 & -.416 & -2.902 & .005 \\
\hline & LN_DER & .034 & .168 & .014 & .201 & .841 \\
\hline & LN_QR & .068 & .133 & .034 & .506 & .615 \\
\hline & LN_EPS & .852 & .101 & 1.226 & 8.411 & .000 \\
\hline
\end{tabular}


$\mathrm{Y}=1,914-0,453 \mathrm{X}_{1}+0,034 \mathrm{X}_{2}+0,068 \mathrm{X}_{3}+$ $0,852 \mathrm{X}_{4}$

Hasil intrepretasi dari regresi tersebut adalah sebagai berikut :

1. Nilai a sebesar 1,914 artinya jika variabel Return On Equity (X1), Debt to Equity Ratio (X2), Quick Ratio (X3), dan Earning Per Share (X4) dianggap konstan, maka Harga Saham (Y) pada perusahaan sector Pertambangan periode 2014-2018 adalah sebesar 1,914.

2. Nilai koefisien Return On Equity (X1) adalah -0,453. Ini menunjukan bahwa setiap peningkatan Return On Equity satu kali, maka Harga Sahamakan mengalami penurunan sebesar 0,453 .

3. Nilai koefisien Debt to Equity Ratio (X2) adalah 0,034. Ini menunjukan bahwa setiap peningkatan Debt to Equity Ratio satu kali, maka Harga Sahamakan mengalami peningkatan sebesar 0,034.

4. Nilai koefisien Quick Ratio (X3) adalah 0,068. Ini menunjukan bahwa setiap peningkatan Quick Ratio satu kali, maka Harga Sahamakan mengalami peningkatan sebesar 0,068 .

5. Nilai koefisien Earning Per Share (X4) adalah 0,852. Ini menunjukan bahwa setiap peningkatan Earning Per Share satu kali, maka Harga Saham akan mengalami peningkatan sebesar 0,852.

Koefisien Determinasi Hipotesis

Tabel IV.6 Koefisien Determinasi Model Summary ${ }^{b}$

\begin{tabular}{|l|r|r|r|}
\hline $\begin{array}{l}\text { Mode } \\
\mathrm{l}\end{array}$ & $\mathrm{R}$ & $\begin{array}{c}\mathrm{R} \\
\text { Square }\end{array}$ & $\begin{array}{c}\text { Adjusted } \mathrm{R} \\
\text { Square }\end{array}$ \\
\hline 1 & $.867^{\mathrm{a}}$ & .752 & .738 \\
\hline
\end{tabular}

a. Predictors: (Constant), LN_EPS, LN_QR, LN_DER, LN_ROE b. Dependent Variable: LN_HARGA_SĀHAM

Sumber : Hasil Pengolahan Data SPSS

Berdasarkan tabel 6 uji koefisien determinasi menunjukkan besarnya nilai $\mathrm{R}$ Square $\left(\mathrm{R}^{2}\right)$ atau koefisien determinasi $\left(\mathrm{R}^{2}\right)$ sebesar 0,752 mengindikasi bahwa variasi dari asset tetap, ukuran perusahaan, likuiditas , Profitabilitas dan tata kelola perusahaan menjelaskan nilai perusahaan sebesar $75,2 \%$ sedangkan sisanya sebesar $24,8 \%$ dipengaruhi oleh variabel lain yang tidak diteliti.

\section{Pengujian Hipotesis Secara Simultan (Uji}

F)

Uji $\mathrm{F}$ digunakan untuk mengetahui apakah semua variabel independen yang dimasukkan dalam model mempunyai pengaruh secara simultan terhadap variabel dependen.

\section{Tabel 4.7 Uji Simultan}

Sumber : Hasil Pengolahan Data SPSS

ANOVA $^{a}$

\begin{tabular}{|l|l|l|l|l|l|}
\hline Model & Sum of Squares & $\mathrm{df}$ & Mean Square & $\mathrm{F}$ & Sig. \\
\hline $\begin{array}{l}\text { Regre } \\
\text { ssion }\end{array}$ & 151.182 & 4 & 37.796 & 52.985 & .000 \\
$\begin{array}{l}\text { Resid } \\
\text { ual }\end{array}$ & 49.933 & 70 & .713 & & \\
Total & 201.115 & 74 & & & \\
\hline
\end{tabular}

a. Dependent Variable: LN_HARGA_SAHAM

b. Predictors: (Constant), LN_EPS, LN_QR, LN_DER, LN_ROE

Berdasarkan table 7 menunjukan nilai $\mathrm{F}$ hitung sebesar 52,985. Pada derajat bebas 1 $(\mathrm{df} 1)=4$, dan derajat bebas $2(\mathrm{df} 2)=70$. Nilai $\mathrm{F}$ tabel pada taraf kepercayaan signifikansi 0,05 adalah 2,790. Oleh karena itu, nilai Fhitung > Ftabel $=52,985>2,749$ maka H0 ditolak, dan HA diterima yang berarti secara simultan Return On Equity Debt to Equity Ratio, Quick Ratio, dan Earning Per Share berpengaruh secara simultan terhadap Harga Saham pada perusahaan sektor Pertambangan periode 2014-2018.

\section{Pengujian Hipotesis Secara Parsial (Uji t)}

Uji statistik $t$ pada dasarnya menunjukkan seberapa jauh pengaruh satu variabel penjelas / independen secara individual dalam menerangkan variabel dependen. 
Tabel 4.8 Uji Parsial

Coefficients $^{a}$

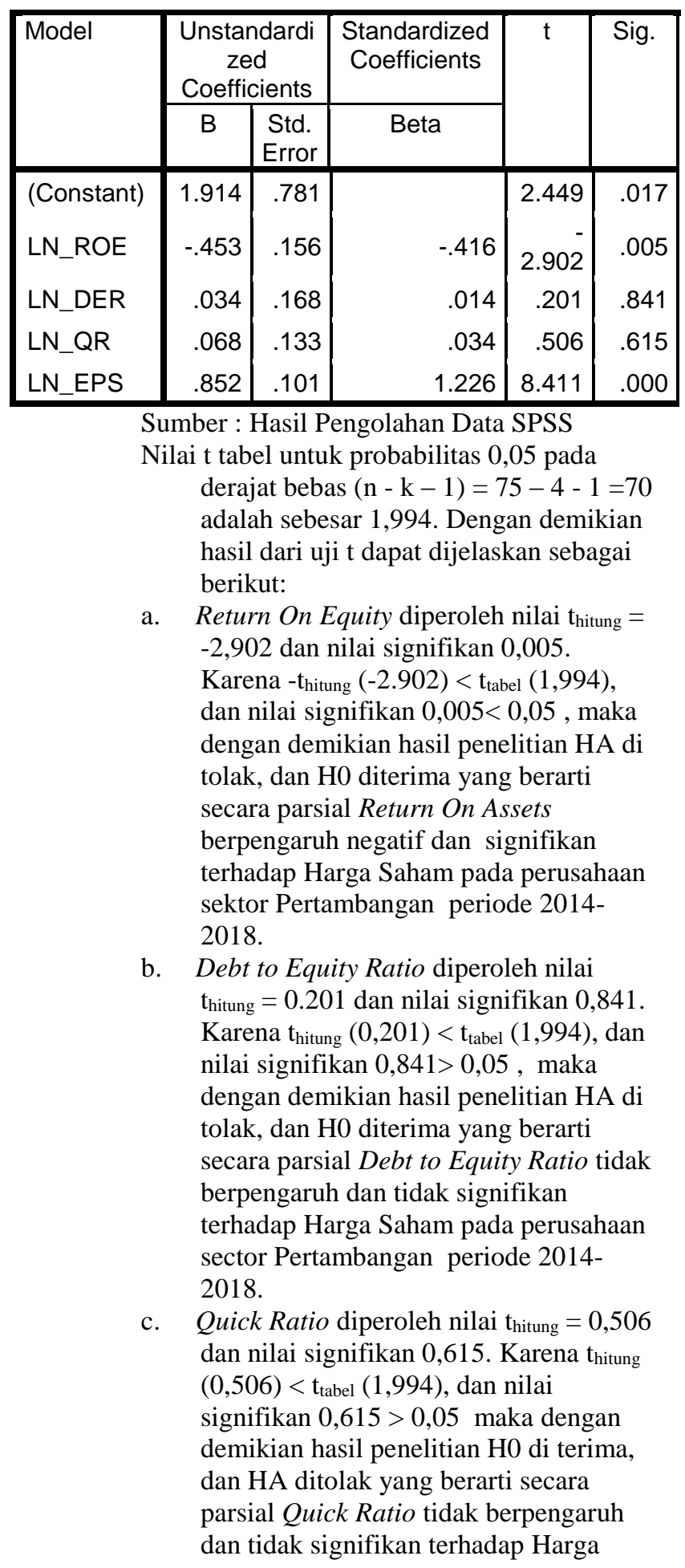

Saham pada perusahaan sektor pertambangan periode 2014-2018.

d. Earning Per Share diperoleh nilai thitung $=8,411$ dan nilai signifikan 0,000 , karena $t_{\text {hitung }}(8,411)>t_{\text {tabel }}(1,986)$, dan nilai signifikan $0,000<0,05$, maka dengan demikian hasil penelitian $\mathrm{H} 0$ di tolak, dan HA diterima yang berarti secara parsial Earning Per Share berpengaruh dan signifikan terhadap terhadap Harga Saham pada perusahaan sektor Pertambangan periode 20142018.

\section{IV.3 Pembahasan}

Pengaruh Return On Equity terhadap Harga Saham. Dari hasil pengujian hipotesis secara statistik diperoleh hasil dengan $t_{\text {hitung }}(-$ $2,902)>t_{\text {tabel }}(1,994)$, dan nilai signifikan $0,005<0,05$, yang menunjukkan bahwa Return On Assets berpengaruh negatif dan signifikan terhadap Harga Saham pada perusahaan sektor Pertambangan periode 2014-2018. Penelitian ini tidak sejalan dengan penelitian yang dilakukan oleh Dorothea Ratih, Apriatni E.P dan Saryadi (2013) yang menyatakan bahwa Return On Equity memiliki pengaruh positif dan signifikan terhadap Harga Saham. ROE mengukur kemampuan perusahaan menghasilkan income berdasarkan modal tertentu. Kenaikkan ROE menandakan meningkatnya kinerja manajemen dalam mengelola sumber dana yang ada untuk menghasilkan laba.

Pengaruh Debt to Equity Ratio terhadap Harga Saham Dari hasil pengujian hipotesis secara statistik diperoleh hasil dengan $t_{\text {hitung }}$ $(0,201)<t_{\text {tabel }}(1,994)$, dan nilai signifikan 0,841>0,05,yang menunjukkan bahwa Debt to Equity Ratio tidak berpengaruh dan tidak signifikan terhadap Harga Saham pada perusahaan sector Pertambangan periode 2014-2018. Penelitian ini tidak sejalan dengan penelitian yang dilakukan oleh Astrid Amanda, Darminto, dan Achmad Husaini (2013) yang menyatakan bahwa Debt to Equity Ratio memiliki pengaruh signifikan terhadap Harga Saham. Dalam penelitian ini hutang tidak perlu dipertimbangan dalam harga saham karena pada perusahaan sector Pertambangan karena untuk penjualannya dilakukan secara kredit. Jadi perusahaan sector Pertambangan memang adalah 
perusahaan yang mengelola hutang dan piutang. Dan umumnya juga para investor telah memahami bahwa untuk berinvestasi dalam perusahaan ini hutang dan piutang tidak perlu dipertimbangkan.

Pengaruh Quick Ratio terhadap Harga Saham. Dari hasil pengujian hipotesis secara statistik diperoleh hasil dengan $t_{\text {hitung }}(0,506)>$ $t_{\text {tabel }}(1,994)$, dan nilai signifikan $0,615<$ 0,05,yang menunjukkan bahwa Quick Ratio tidak berpengaruh dan tidak signifikan terhadap Harga Saham pada perusahaan sector pertambangan periode 2014-2018. Penelitian ini tidak sejalan dengan penelitian yang dilakukan oleh Ummu Putriana Hanie dan Muhammad Saifi (2018) yang menyatakan bahwa Quick Ratio memiliki pengaruh negatif terhadap Harga Saham. Pada perusahaan Pertambangan, perusahan kebanyakan melakukan kegiatan transaksi dengan menggunakan utang jangka panjang. Sehinggan investor tidak terlalu memperhitungkan likuiditas dalam menanamkan modalnya kedalam perusahaan sector pertambangan.

Pengaruh Earning Per Share terhadap Harga Saham. Dari hasil pengujian hipotesis secara statistik diperoleh hasil dengan $\mathrm{t}_{\text {hitung }}(8,411)<\mathrm{t}_{\text {tabel }}(1,994)$, dan nilai signifikan $0,000<0,05$,yang menunjukkan Earning Per Share memiliki pengaruh positif dan signifikan terhadap Harga Saham pada perusahaan sektor Pertambangan periode 2014-2018. Penelitian ini sejalan dengan penelitian yang dilakukan oleh Dwi Rahmawati dan Bambang Suryonon (2017) yang menyatakan bahwa Earning Per Share memiliki pengaruh postiif dan signifikan terhadap Harga Saham. Earning Per Share berpengaruh positif karena semakin tinggi EPS perusahaan pertambangan, semakin tinggi laba yang akan dibagikan kepada investor atau pemegang saham perusahaan. Investor akan berfikir perusahaan pertambangan mampu mengelola perusahaan dengan baik dan memperoleh laba yang lebih tinggi sehingga investor mau menanamkan modal nya ke perusahaan Pertambangan.

\section{KESIMPULAN DAN SARAN}

Kesimpulan dari hasil penelitian ini secara parsial Earning Per Share berpengaruh positif dan signifikan terhadap Harga Saham pada perusahaan sector Pertambangan periode 2014-2018. Return On Equity berpengaruh negative dan signifikan terhadap Harga Saham pada perusahaan sector Pertambangan periode 2014-2018, sedangkan Debt to Equity Ratio dan Quick Ratio tidak berpengaruh terhadap Harga Saham pada perusahaan sector Pertambangan periode 2014-2018. Dan hasil penelitian secara simultan Return on Equity, Debt to Equity Ratio, Quick Ratio dan Current Ratio berpengaruh terhadap Harga Saham pada perusahaan sektor Pertambangan periode 2014-2018.

\section{UCAPAN TERIMA KASIH}

Selama menyelesaikan penyusunan jurnal ini penulis telah banyak menerima bantuan dari berbagai pihak, baik secara langsung maupun tidak langsung. Untuk itu, dengan segala kerendahan hati, penulis ingin menyampaikan ucapan terima kasih yang sebesar-besarnya kepada semua pihak yang turut membantu terutama untuk Politeknik Ganesha Medan yang telah mengizinkan kami untuk mempublikasikan jurnal kami.

Saran dari hasil penelitian ini Bagi investor ataupun calon investor yang akan menanamkan modalnya dalam suatu perushaan, sebaiknya jangan hanya berpacu pada analisis rasio yang peneliti lakukan saja karena masih banyak faktor lain yang tidak disebutkan dalam penelitian ini yang bisa menunjukkan nilai perusahaan berdasarkan harga sahamnya. Mengingat variabel bebas dalam penelitian ini merupakan hal yang sangat penting dalam mempengaruhi Closing Price diharapkan hasil penelitian ini dapat dipakai sebagai acuan bagi peneliti selanjutnya untuk mengembangkan penelitian ini dengan mempertimbangkan variabelvariabel lain yang merupakan variabel lain diluar variable yang sudah masuk dalam penelitian ini.

\section{DAFTAR PUSTAKA}

Saifi. 2015 "Pengaruh Rasio Likuiditas dan Rasio Leverage Terhadap Harga Saham ( Studi pada perusahaan 
Indeks LQ 45 Periode 2014

2016)".Jurnal Administrasi Bisnis

Darmadji, Tjiptonodan Hendy M. Fakhruddin 2015.Pasar Modal Di Indonesia:

Tanya Jawab. Ed. 3,Jakarta: Salemba Empat

Fahmi, Irham. 2015. Manajemen Investasi:

Teori dan Soal Jawab. Ed. 2, Jakarta:Salemba Empat

Hery. 2015. Analisa Laporan Keuangan Pendekatan Rasio Keuangan. Cetakan Pertama.Yogyakarta : PT Buku Seru.

Houston, Brigham. 2012. Dasar-Dasar Manajemen Keuangan. Ed. 11, Jakarta: Salemba Empat.

Kasmir. 2010. Pengantar Manajemen

Keuangan. Jakarta: Kencana Prenada Media Group.

Kodrat, David Sukardi \& Indonanjaya.2010.

Manajemen Investasi: Pendekatan Teknikal danFundamental untuk Analisis Saham. Cetakan Pertama. Yogyakarta: Graha Ilmu.

Zubir, Zalmi. 2011. Manajemen Portofolio Penerapannya Dalam Investasi Saham. Jakarta: Salemba Empat
Nurfadillah, Mursidah. 2011. “Analisis Pengaruh Earning Per share, Debt to Equity Ratio dan Return On Equity Terhadap Harga Saham PT. UnileverTbk".Jurnal Manajemen dan Akuntansi April 2011 Vol. 12 No. 1

Ratih, Dorothea. 2013. "Pengaruh EPS, PER, DER, ROE Terhadap Harga Saham Pada Perusahaan Sektor Pertambangan Yang Terdaftar Di Bursa Efek Indonesia (BEI) Tahun 2010-2012".Diponegoro Journal Of Social And Politic.

Sudana, I Made. 2011. Manajemen Keuangan Perusahaan teori Dan Praktek. Bandung : Erlangga

Wuryaningrum, Reni (2015). Pengaruh Rasio Keuangan terhadap Harga Saham pada perusahaan Farmasi di BEI, Jurnal Sekolah Tinggi Ilmu Ekonomi Indonesia (STIESIA) Surabaya 